\title{
茅ヶ崎海岸における BMSの被災原因とその改良方策
}

\author{
平野浩一*・千田昌平**・和田信昭 $* * *$ \\ 宇多高明 $* * * *$. 見附敬三****
}

\section{1. まえがき}

近年，海浜の浸透性を向上させることにより，海浜へ の堆積を促そうとする工法が各地で試みられるように なった. 浸透性を向上させる手法として, 柳島ら (1995； 1996）は，汀線と直交するトレンチに浸透性の良好な砂 礫を敷き詰め, 自然流下で地下水を排除する方法を検討 した。一方，最近では汀線と平行に集水管を設置する方 法 (Beach Management System; BMS) も提案されて いる. BMSにより地下水位を下げて砂浜の浸透性を向 上させ, 汀線付近への堆砂を促す場合, その効果を高め ようとするならば, BMSの位置をできるだけ海側に設 置したくなる.しかし，地下の集水管位置を海側にすれ ばするほど，波による海浜の変動量も大きくなるから， 高波浪時, 集水管が海底面に露出して壞れる危険性も高 くなる.一方, 現地海岸では沿岸漂砂の作用が強いので, 無限に長い海岸線を持つ場合を除いて, 有限長の海岸線 を持った区域に BMS を設置する場合には，その周辺の 構造物が沿岸漂砂を阻止することによる汀線変動にも十 分な注意が必要である.しかしこれらの点を考慮した設 計法は確立していない.

最近，茅ヶ崎海岸ではパイロット事業として BMS の 試験運用がなされ，その効果検討が行われたが，試験期 間中の 1996 年 9 月 22 日に来襲した台風 17 号の高波浪 により，集水管が露出し壊れた。本研究は，この被災原 因について検討し, 今後の改良計画について検討するも のである、なお, 茅ヶ崎海岸における BMS工法の検討 は, 神奈川県が (財) 土木研究センター, (財) 神奈川県 都市整備技術センターとの共同研究として進めているも のである.

\section{BMS 試験区域における長期的海浜変形}

BMS の試験は, 相模湾に面した湘南海岸東部の茅ヶ 崎海岸で行われた。この海岸における潮位は, 朔望平均

\begin{tabular}{|c|c|c|}
\hline$*$ & & 神奈川県湘南なぎさ事務所副技幹 \\
\hline ** 正会員 & 工博 & (財)土木研究センター常務理事 \\
\hline$* * *$ & & (財) 土木研究センター部長 \\
\hline **** 正会員 & 工博 & 建設省土木研究所河川部長 \\
\hline ****** 正会員 & 工修 & 日本建設コンサルタント (株) \\
\hline
\end{tabular}

満潮位が T.P.0.64 m, 干潮位がー0.93 m にあり,また試 験区域の西 $5.5 \mathrm{~km}$ に位置する科学技術庁防災技術研究 所の「平塚沖」波浪観測によれば, エネルギー平均波高 は $0.83 \mathrm{~m}$, 周期は $6.3 \mathrm{~s}$ である. 茅ヶ崎海岸には 1991 年 までに堤長 $160 \mathrm{~m}$, 基部からへッド部までの沖向き距離 $230 \mathrm{~m}$ のヘッドランドが侵食対策として建設されてい る. 図一1には, このヘッドランドと茅ヶ崎漁港周辺の深 浅図を示す.同時に長期的海浜変形を調べるために, 1987 年 5 月と 1996 年 3 月の深浅図を重ね合わせ侵食・堆積域 の区別を付けている. 両者を比較すると, ヘッドランド の周辺区域と茅ヶ崎漁港の防波堤の遮蔽域に入る漁港の 東側隣接部で堆積が進んでいる.とくにへッドランドの 周辺域での堆積が著しい.ヘッドランド周辺では, 図-2 に示すように経年的に養浜が行われてきた.したがって ヘッドランド周辺での堆積土砂の多くは養浜に起因して いる.しかしながら, ヘッドランドと茅ヶ崎漁港の中央 部のー4〜-9 m の間では広い範囲で等深線が後退し, 侵 食が進んでいることから, ヘッドランド周辺および茅ヶ 崎漁港の東側隣接部での堆積土砂には, 中央部の侵食土

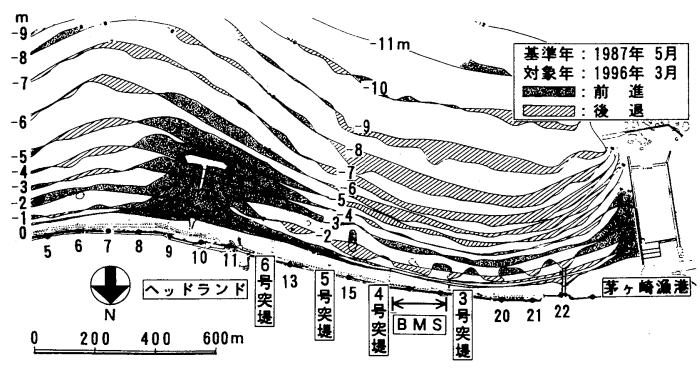

図-1 茅ヶ崎海岸のヘッドランドと茅ヶ崎漁港周辺の海浜 変形

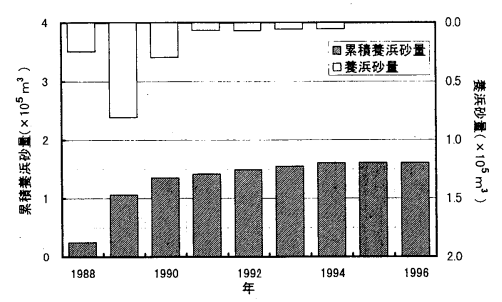

図一2茅ヶ崎海岸における養浜工の経過 


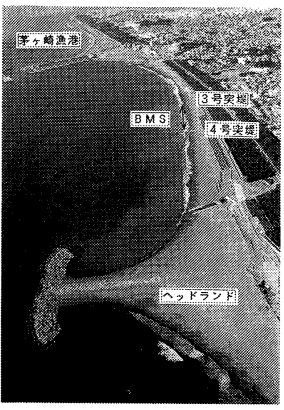

写真一1 ヘッドランド〜茅ヶ崎漁港間の全体的海浜状況 (1996 年 12 月 20 日撮影)

砂も含まれていると考えられる．海浜の両側に波の遮蔽 構造物があるために, 中央部の前浜が狭い場所で養浜し ても養浜砂はそこには止まらず，両側の波の静穏な区域 へと移動する.このことは, 養浜をよほど大量に行わな い限り, 中央部の前浜が狭い区域で堆砂を進めることは 困難であることを意味する。こうしたことから，前浜を 少しでも拡大し侵食防止を図ることを目的として BMS が設置された。

写真一 1 は, ヘッドランドの東側から茅ヶ崎漁港を望 む海浜状況である. 写真に示すように，ヘッドランドよ り西向きに砂浜幅は次第に狭くなるが, 砂浜幅が最も狭 くなる付近にBMS は設置された。図一1に示したよう に,この付近は両側を施設に挾まれているために, 相対 的に波高が高く，かつ長期的にみてその沖合部が侵食さ れて深くなりつつある区域である。したがってそこでは 海浜の地形変動量も大きいことが想定された.このこと は侵食制御のための設置の理由を与える反面, BMSの 耐久性の確保がかなり難しいことを意味している.

\section{BMS の試験施工}

BMS は, 平均汀線付近において, 海浜変動を考慮して 初期におけるかぶり厚を約 $1.7 \mathrm{~m}$ として設計された。集 水管は, 汀線とほぼ平行に, 沿岸方向 $180 \mathrm{~m}$ の範囲に設 置された. 集水管は 2 本の径 $0.3 \mathrm{~m}$ の透水管（ポリプロ ピレン製）であり，前浜背後に掘られた井戸まで海水を 自然流下させ, 貯水槽に設置されたポンプ（最大流量 $0.139 \mathrm{~m}^{3} / \mathrm{s}$ )により海水を吸い上げる構造を有する.配管 工事はドライ施工とするために，写真一 2 に示すように， 突堤に㣣まれた区域に矢板を打ち，海水の侵入防止を 図った上で 1996 年 3 月までに行われた。 その後 1996 年 5 月 17 日から試験運転に入ったが，図一 3 に示すよう に，5月20日には東端から $20 \mathrm{~m}$ が被災したので直ちに 仮復旧を行った. 7 月 10 日には台風 5 号の波浪によりさ らに $40 \mathrm{~m}$ が，そして 9 月 22 日には台風 17 号の高波浪 により全長 $40 \mathrm{~m}$ 部分が海底面に露出し, 集水管に直接

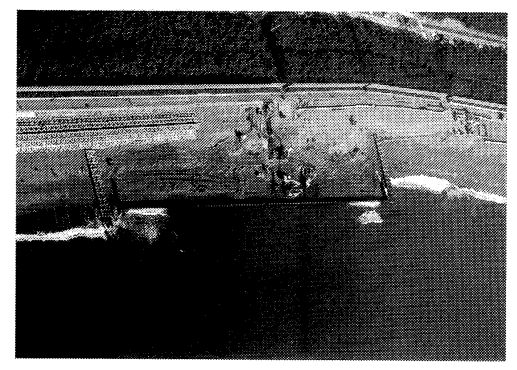

写真一2 BMS 工事中の海岸線状況（1995 年 12 月 21 日撮 影)

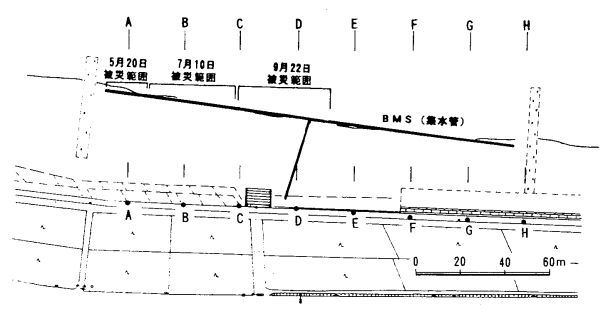

図一３ＢMS の被災範囲

砂が流入するとともに，集水管が破損したため試験を中 断した.

なお，写真一 2 に示す突堤周辺の汀線形状を調べると， 左側に位置する 3 号突堤の左（西）側の汀線に対して 4 号突堤の右 (東) 側の汀線は明らかに後退している.こ のことは，この写真を撮影した 1995 年 12 月頃には西寄 りの入射波条件により東向きの沿岸漂砂が卓越していた ことを示している.

\section{BMS 周辺の短期的海浜変動}

図-4には，深浅測量データから求めた試験期間中の 砂浜幅の沿岸分布を示す。図には汀線の前進・後退の区 別を付けるとともに，限界砂浜幅の目安として砂浜幅 30 mの線を記入している。これによれば, BMS はへッドラ ンドと茅ヶ崎漁港の間で砂浜幅が $30 \mathrm{~m}$ を切り, 最も砂 浜幅が狭い付近で導入されたことになる。 また，汀線変 化を調べると，汀線が鋭角状に突出したヘッドランド背 後において，3月から 11 月にはヘッドランドの東側で汀 線が前進し，このとき同時にへッドランド西側の No. 13, 14 付近では汀線が後退している. 不透過構造物である ヘッドランドを挾んで東側で汀線が前進, 西側で後退す る特徵は,この間東側からの入射波が卓越し,これによっ て西向きの沿岸漂砂が卓越していたことを表している.

写真一 3 は, 1996 年 6 月 7 日に打ける 3 号突堤周辺の 汀線状況を示したものである. 突堤の左（東）側の汀線 が西側に比較して前進しており, 西向きの沿岸漂砂の卓 越を表すが,この結果は図一4の結果と調和的である.さ らに, 写真-4 は 1996 年 9 月 12 日の海岸状況であるが, 
手前側の 3 号突堤を境に西側の汀線が後退している。こ の状況もまた，写真一 3 で見られた特徵と同一傾向であ る.したがって写真-3 の撮影時期 (1996 年 6 月 7 日)か ら写真-4 の撮影時期 (1996 年 9 月 12 日) の間では, 東 寄りの入射波向のもとで西向きの沿岸漂砂が発達してい たことがわかる。

このような沿岸漂砂の方向は, 写真一 2 に示した工事 中の状況と全く逆転していることが注目される。すなお ち茅ヶ崎海岸では, 波向変動に伴ってサイクリックモー ドの汀線変動が生じることで特徵付けられる.

図一5 は, BMS の設置区域を㣣む 2 基の突堤間におけ る 1996 年 4 月 17 日〜 9 月 6 日の汀線変化を示す.この 間, 4 号突堤の西側隣接部で汀線が後退し， 3 号突堤の 東側隣接部では前進している. 以上の状況は, 写真から 得られた特徵と同じである。9月 6 日のように 4 号突堤 の西側隣接部が後退した状態において, 9 月 22 日に高波 浪が作用したため, BMS は中央より東側が一部露出し た上，被害を被った。

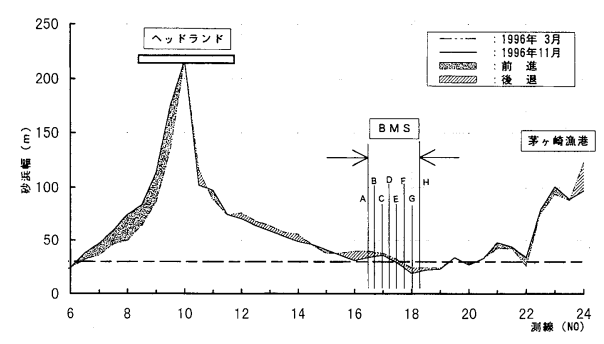

図-4 砂浜幅の沿岸方向分布

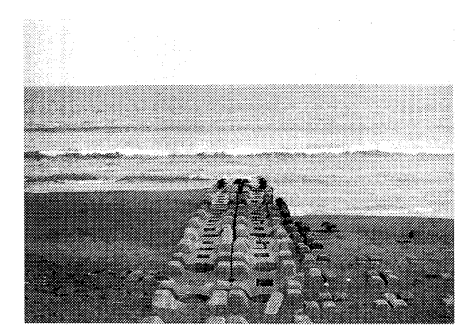

写真-3 3 号突堤周辺の汀線状況（1996 年 6 月 7 日撮影）

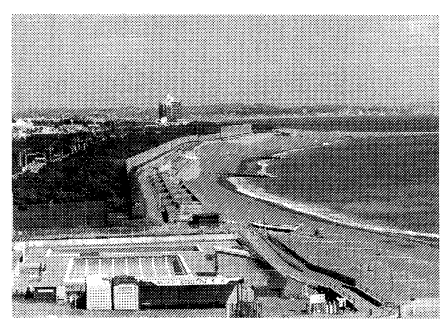

写真-4 茅ヶ崎漁港側から BMS 試験区間を望む状況 (1996 年 9 月 12 日撮影) 写真一5（a）は，台風来襲直前の 9 月 18 日に抢ける 3 号突堤周辺の海岸状況である。9 22 日には台風 17 号 に伴う高波浪（茅ヶ崎海岸の西 $5.5 \mathrm{~km}$ に位置する平塚 沖観測所での $\left.H_{1 / 3}=2.4 \mathrm{~m}\right)$ が来襲した。平型ブロック製 の突堤の左（東）側の汀線が前進し，ブロックの大部分 には砂が被さっていることが見て取れる。同じく台風来 襲時の写真一5 (b)ではブロック上の砂は洗い流され，ブ ロックが露出している.ブロックの幅が約 $2 \mathrm{~m}$ であるこ とを考慮すると, $1 \mathrm{~m}$ 程度砂浜の地盤高が低下したこと がわかる.

BMS の安定性にはかぶり厚が大きく関与する。そこ で, 1996 年 4 月 17 日〜 9 月 24 日の測量デー夕をもと に, BMS 上のかぶり厚の沿岸方向分布を調べた. 図一6 に結果を示す. 工事完成直後の 4 月 17 日では, かぶり厚 はやや東側で小さいが, 全体的にほぼ $1.5 \mathrm{~m}$ 程度以上の かぶり厚を有していた。しかし，6月 6 日では 4 号突堤 の西側隣接部でかぶり厚が減少し，これと対照的に 3 号 突堤の東側隣接部でのかぶり厚の増加が見られる。すな わちこの期間において突堤間でのシーソーモードの汀線

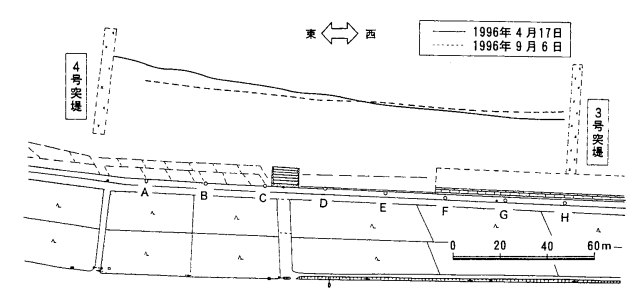

図一5 BMS 設置区間に抢ける短期的汀線変化

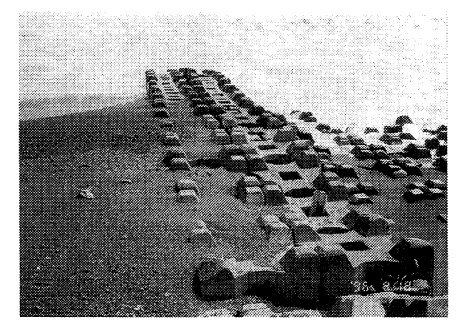

（a）台風来襲前の 1996 年 8 月 18 日

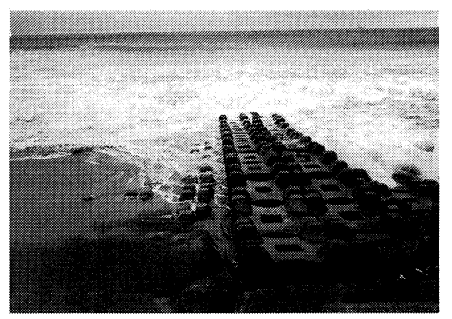

（b）台風来襲時の 1996 年 9 月 22 日 写真-5 3 号突堤周辺の海浜状況 


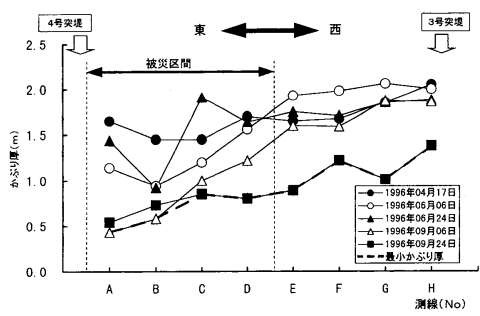

図一6 BMS 上のかぶり厚の沿岸方向分布

変化が発生し始めた。しかしながら，それでも最小のか ぶり厚は約 $1 \mathrm{~m}$ はあった。 6 月 24 日には測線 B を除い て測線 D より東側ではかぶり厚が増加し, 測線 $\mathrm{E}$ より西 側では緩やかにかぶり厚が減少している．全体的には突 堤間でシーソーモードを有するが，測線 C 付近では測線 Aよりもはるかに大きくかぶり厚が増加している。その 変化傾向から，波向変動に伴う海浜変形とは考えにくい から，局所的なかぶり厚の増加は BMS の効果が現れた ものと考えられる。しかし 9 月 6 日になると, 中央より 東側でかぶり厚が減少し，とくに東端のかぶり厚は 0.5 $\mathrm{m}$ 以下となった。さらに 9 月 24 日の台風来襲直後では, 左右の汀線がシーソーモードを示さないことから判断す ると，高波浪による沖向き漂砂に起因して全体にかぶり 厚が大きく滅少したと考えられる。

图一6には以上 5 回の観測值にもとづくかぶり厚の最 小值を破線で示す。最小值は, 被災直後の 9 月 24 日の測 定値の影響を強く受けているが，観測区域の東端で最小 の約 $0.5 \mathrm{~m}$ を示し, 西端では約 $1.4 \mathrm{~m}$ と東西で $1 \mathrm{~m}$ 近い 差がでている．BMS の被災は中央より東側で著しかっ たことから，図一6 はその状況をよく説明しており，かぶ り厚がほほ $0.8 \mathrm{~m}$ 以下となると安定性に障害が出ると 言える，ただし，図示する台風後のかぶり厚は，台風後 の測量によるものであって高波浪の作用中ではない. 実 際には図示するかぶり厚より洗掘が進んで集水管が露出 したか，あるいは集水管の露出はないものの海底面に水 みちが形成されたことによって破壊されたかは確認でき ない.したがって安全性を考えると，かぶり厚は約 $1 \mathrm{~m}$ は必要と考元られる。

実際には，最小かぶり厚が与えられたのみでは設計で きない．なぜなら，ある時刻の海浜綐断形が与えられた としても，それが侵食された状態にあるのか，あるいは 堆積した状態にあるかによって結果が大きく異なるから である，侵食され切った状態で最小かぶり厚を与えれば 安全側となるが，堆積した状態では危険側となる。した がって海浜の平均断面形との関係において議論し，ある 時刻の海浜綐断形と平均断面形との差異については別に 検討する必要がある。このことから，図一7には，突堤間 に扔いて $50 \mathrm{~m}$ 間隔で並んだ測線 A, C, E, G を選んで,
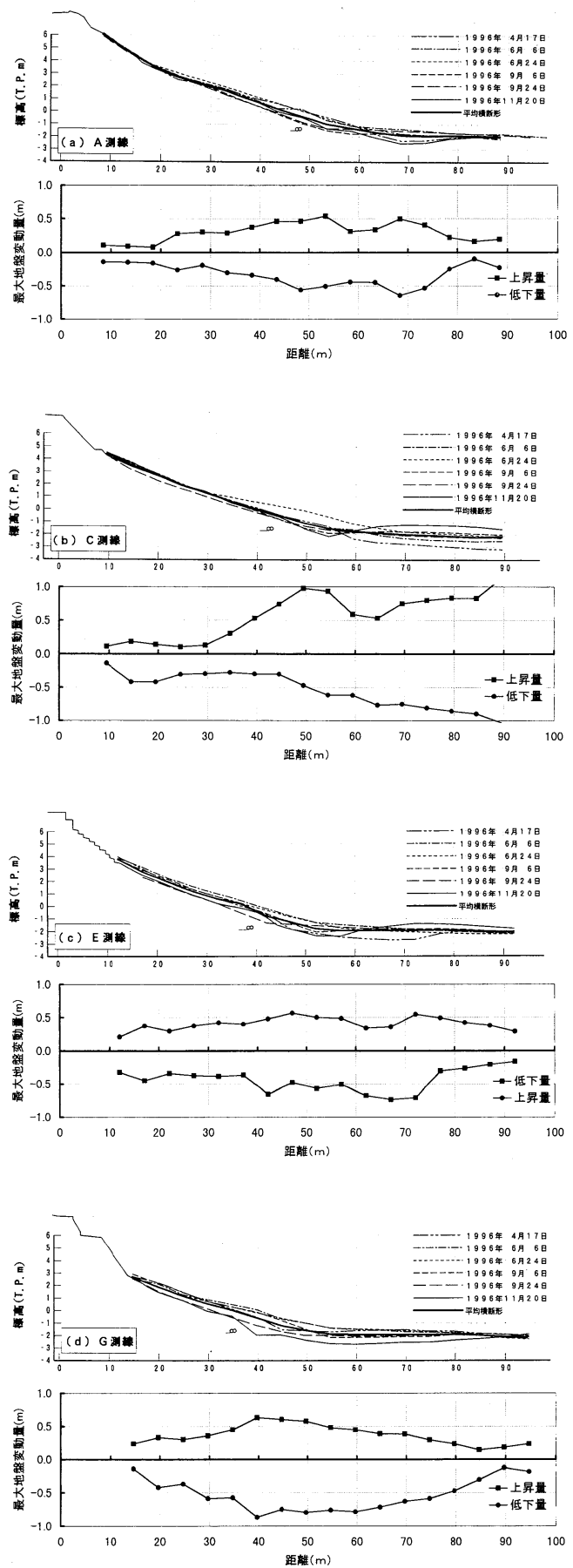

図一7 海浜縦断形の変化と最大地盤変動量の岸沖分布

観測期間中の深浅測量データをもとに，海浜縦断形，平 均縦断形およびそれにのる地盤変動量の岸沖分布を示 す．併せて集水管位置も示す．

平均縦断形にのる地盤変動量において, 海底地盤が低 下する場合についてみると，A〜G 測線とも海浜地盤高 
の低下量は前浜から汀線へと増加し，汀線付近で最大值 をとる。もしシーソーモードの海浜縦断形の変化が著し く卓越するのであれば，突堤間の中央部では両側より変 動量が相対的に小さく出るはずであるが，これらの図で はそのような特性は見られない.したがって，この地盤 変動量には突堤間でのシーソーモードによる地形変化 と, 岸沖漂砂による地形変化が重なっており，両者の区 別はかなり難しいと考えられる。そこで安全側として， 図示する変動が全て岸沖漂砂に起因するとして平均値を 求めると，汀線付近では平均約 $0.5 \mathrm{~m}$ である。このこと は汀線付近に BMS を設置する場合，平均縦断形よりも 約 $0.5 \mathrm{~m}$ 下方までは海底面が低下しうることを意味す る。これに加えて前述のように約 $1.0 \mathrm{~m}$ のかぶり厚を必 要とする。なお，設置位置が汀線より岸側となればその 分地盤変動量は小さくなるので，かぶり厚は小さくする ことができる。

\section{5. 観測井戸による地下水レベルの観測}

1996 年 5 月 17 日からの試験運用に際して，海浜の地 下水レベルの変化を観測井戸により観測した。観測井戸 は測線 B 付近の前浜上 T.P.2 $\mathrm{m}$ 付近に設置して, 地下水 位の経時観測を行った。併せて潮位データとして「平塚 沖」のデー夕を収集した，図一 8 には観測結果を示す．観 測井戸付近の地下水位は $0 \sim 1.2 \mathrm{~m}$ の間で変動し，潮位 変化に対して約 1 時間の位相遅れを有している。集水は 5 月 17 日の 11 時から開始されたが, 集水開始とともに, 地下水レベルに変動が現れた. 図一9には, 地下水と潮位 の変動状況を比較するために，両者の相関を示す。これ によれば，集水前の水位（○印）に対して，集水後の水 位（○印）には明らかに低下が認められる。集水後には 変動量が大きいが，平均的に潮位が T.P. $0.5 \mathrm{~m}$ で 0.16 $\mathrm{m}$, T.P. $0 \mathrm{~m}$ で $0.20 \mathrm{~m}$, T.P. $-0.5 \mathrm{~m}$ で $0.25 \mathrm{~m}$ の水位低 下が認められ，BMSにより海浜部の地下水低下効果が 現れたことがわかる。

\section{6. まと め}

茅ヶ崎海岸での BMS の現地実験では，実験期間中に 集水管の一部が海底面に露出し, 試験体の一部が破損し

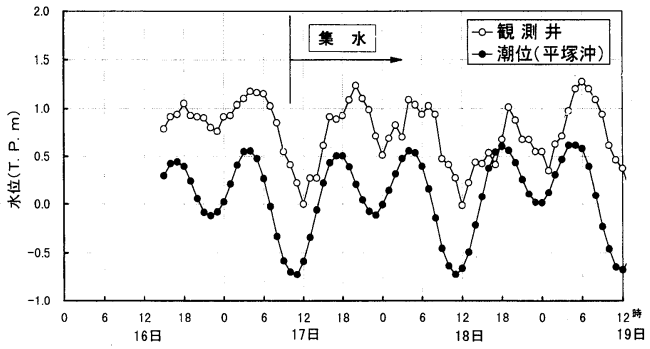

図一8，海浜の地下水レベルと潮位の経時的変化

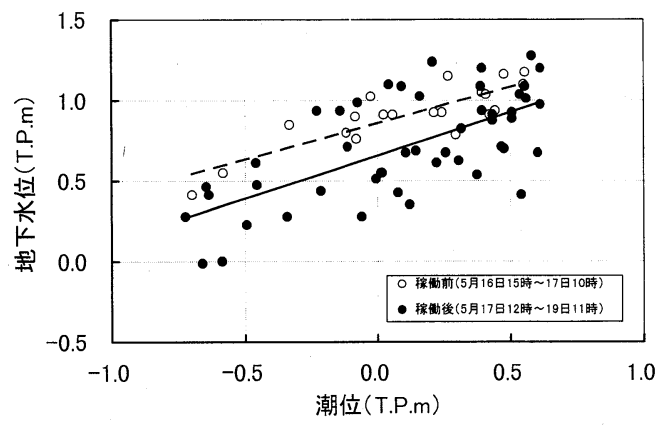

図一9 地下水レベルと潮位の相関

た.その原因としては，集水管位置がやや海側過ぎ，そ こでの海底面変動に対してかぶり厚が不足したことがあ げられる。また, BMS 設置区間の両側に設置された突堤 によるサイクリックモードの汀線変化が生じたことがか ぶり厚の低下を招いた主因であることがわかった。この ことから, 汀線付近に BMS を設置する場合には, 平均海 浜縦断形に対して約 $0.5 \mathrm{~m}$ の海浜地盤高の低下を見込 んだ上,さらに最小かぶり厚約 $1.0 \mathrm{~m}$ が満足されるよう 集水管を設置すべきことが必要と言える.

\section{参 考 文 献}

柳島慎一・加藤一正・天坂勇治・名城 整・望月徳雄 $(1995)$ ：現 地海岸に埋設した透水管の排水流量と前浜地形変化, 海岸工 学論文集, 第 42 巻, pp. 726-730.

柳島慎一・金澤 寛・平井宣典・加藤一正・望月徳雄 (1996)： ス トライプ状透水層の前浜地形変化に及活す三次元効果, 海岸 工学論文集, 第 43 巻, pp. 661-665. 